\title{
Angiotensin II: a hormone that affects lipid metabolism in adipose tissue.
}

Citation for published version (APA):

Goossens, G. H., Blaak, E. E., Arner, P., Saris, W. H., \& van Baak, M. A. (2007). Angiotensin II: a hormone that affects lipid metabolism in adipose tissue. International Journal of Obesity, 31(2), 382-384. https://doi.org/10.1038/sj.ijo.0803388

Document status and date:

Published: 01/01/2007

DOI:

10.1038/sj.ijo.0803388

Document Version:

Publisher's PDF, also known as Version of record

\section{Please check the document version of this publication:}

- A submitted manuscript is the version of the article upon submission and before peer-review. There can be important differences between the submitted version and the official published version of record.

People interested in the research are advised to contact the author for the final version of the publication, or visit the DOI to the publisher's website.

- The final author version and the galley proof are versions of the publication after peer review.

- The final published version features the final layout of the paper including the volume, issue and page numbers.

Link to publication

\footnotetext{
General rights rights.

- You may freely distribute the URL identifying the publication in the public portal. please follow below link for the End User Agreement:

www.umlib.nl/taverne-license

Take down policy

If you believe that this document breaches copyright please contact us at:

repository@maastrichtuniversity.nl

providing details and we will investigate your claim.
}

Copyright and moral rights for the publications made accessible in the public portal are retained by the authors and/or other copyright owners and it is a condition of accessing publications that users recognise and abide by the legal requirements associated with these

- Users may download and print one copy of any publication from the public portal for the purpose of private study or research.

- You may not further distribute the material or use it for any profit-making activity or commercial gain

If the publication is distributed under the terms of Article $25 \mathrm{fa}$ of the Dutch Copyright Act, indicated by the "Taverne" license above, 


\title{
Angiotensin II: a hormone that affects lipid metabolism in adipose tissue
}

\author{
GH Goossens ${ }^{1}$, EE Blaak ${ }^{1}$, P Arner $^{2}$, WHM Saris $^{1}$ and MA van Baak ${ }^{1}$ \\ ${ }^{1}$ Department of Human Biology, Nutrition and Toxicology Research Institute Maastricht (NUTRIM), Maastricht University, \\ Maastricht, The Netherlands and ${ }^{2}$ Department of Medicine, Huddinge University Hospital, Karolinska Institute, Stockholm, \\ Sweden
}

Background: Alterations in adipose tissue lipolysis may contribute to the pathophysiology of obesity and insulin resistance. We examined the effects of angiotensin II (Ang II) on abdominal subcutaneous adipose tissue lipolysis in humans.

Methods and results: First, adipocytes obtained from nine normal weight and seven obese subjects were stimulated with Ang II $\left(10^{-14}-10^{-6} \mathrm{M}\right)$. Glycerol concentration in the medium, used as an indicator of adipocyte lipolysis, was significantly reduced ( $\sim 20 \%)$ after Ang II stimulation in adipocytes from normal weight $(P=0.04)$ and obese subjects $(P<0.001)$. Based on these observations, adipocytes of seven additional obese subjects were stimulated with lower doses of Ang II $\left(10^{-17}-10^{-6} \mathrm{M}\right)$ in the presence and absence of Ang II type $1\left(\mathrm{AT}_{1}\right)$ receptor blockade. Lipolysis was dose dependently inhibited by $\sim 20$ to $25 \%$ after Ang II stimulation $(P=0.001)$. $\mathrm{AT}_{1}$ receptor blockade completely abolished the Ang II-induced effects $(P=0.35)$.

Conclusion: Ang II directly inhibits abdominal subcutaneous adipocyte lipolysis in normal weight and obese subjects via the $\mathrm{AT}_{1}$ receptor.

International Journal of Obesity advance online publication, 16 May 2006; doi:10.1038/sj.ijo.0803388

Keywords: angiotensin II; Ang II type 1 receptor; lipolysis; adipose tissue

\section{Introduction}

Abdominal obesity is strongly associated with insulin resistance. Part of this association may be explained by adipose tissue products that exert autocrine, paracrine and/ or endocrine effects that may affect metabolism. ${ }^{1-3}$

A functional renin-angiotensin system (RAS) is present in human adipose tissue, ${ }^{4-6}$ and local generation of angiotensin II (Ang II), the effector molecule of the RAS, by human (pre)adipocytes has been demonstrated. ${ }^{7}$ The adipose tissue RAS may be involved in obesity-related disorders, such as insulin resistance, ${ }^{8,9}$ possibly through an effect on adipocyte differentiation. ${ }^{10,11}$ Furthermore, direct lipogenic effects of Ang II in human adipocytes have been shown, ${ }^{12}$ and recent data from our laboratory suggest that Ang II may inhibit lipolysis in vivo in human adipose tissue and skeletal muscle. ${ }^{13}$ However, no conclusions about the magnitude of the observed antilipolytic effects of Ang II could be drawn from these findings, as the Ang II-induced decrease in tissue

Correspondence: Dr GH Goossens, Department of Human Biology, Nutrition and Toxicology Research Institute Maastricht (NUTRIM), Maastricht University, PO Box 616, Universiteitssingel 50, 6200 MD Maastricht, The Netherlands. E-mail: G.Goossens@hb.unimaas.nl

Received 18 November 2005; revised 5 April 2006; accepted 8 April 2006 blood flow may have masked direct effects on lipolysis to some extent. The objective of the present study was to investigate for the first time the direct effects of Ang II on abdominal subcutaneous adipose tissue lipolysis in vitro in normal weight and obese subjects.

\section{Materials and methods}

Nine normal weight and seven obese male subjects participated in the first study. Seven additional obese subjects participated in a second experiment. Characteristics of the subjects are summarized in Table 1 . The Medical-Ethical Committee of Maastricht University approved the study protocol and all subjects gave written informed consent before participating in the study.

\section{Protocol}

Abdominal subcutaneous adipose tissue ( $\sim 2 \mathrm{~g})$ was obtained by needle aspiration under local anesthesia after an overnight fast. Adipocytes were isolated from the subcutaneous fat tissue specimen as described previously. ${ }^{14}$ Firstly, diluted suspensions of adipocytes ( $\sim 5000-10000$ cells/incubation) from normal weight and obese subjects were incubated with 
Table 1 Subjects' characteristics

\begin{tabular}{lccc}
\hline & Normal weight & Obese (study 1) & Obese (study 2) \\
\hline Age (years) & $54 \pm 2$ & $51 \pm 2$ & $52 \pm 4$ \\
Weight $(\mathrm{kg})$ & $76.5 \pm 1.9$ & $112.8 \pm 6.4^{*}$ & $109.1 \pm 6.3^{\#}$ \\
Height $(\mathrm{m})$ & $1.78 \pm 0.03$ & $1.78 \pm 0.02$ & $1.81 \pm 0.02$ \\
BMl $\left(\mathrm{kg} / \mathrm{m}^{2}\right)$ & $24.3 \pm 0.4$ & $35.5 \pm 1.8^{*}$ & $33.3 \pm 1.9^{\#}$ \\
Body fat (\%) & $22.9 \pm 1.3$ & $34.6 \pm 2.7^{*}$ & $34.4 \pm 3.1^{\#}$ \\
\hline
\end{tabular}

Abbreviation: BMI, body mass index. Values are means \pm s.e.m. ${ }^{*} P=0.001$ vs normal weight by unpaired $t$-test; ${ }^{\#} P<0.005$ vs normal weight by unpaired $t$-test.

Ang II $\left(10^{-14}-10^{-6} \mathrm{M}\right.$; Sigma-Aldrich, Zwijndrecht, The Netherlands) for $2 \mathrm{~h}$ at $37^{\circ} \mathrm{C}$ in Krebs-Ringer phosphate buffer. Thereafter, incubation medium was immediately frozen in liquid nitrogen and stored at $-80^{\circ} \mathrm{C}$ until analysis. Glycerol concentration in the medium, determined using a sensitive automated bioluminescence method, ${ }^{15}$ was used as an indicator of lipolysis.

Adipocytes of an additional group of obese subjects were stimulated with lower Ang II concentrations $\left(10^{-17}-10^{-6} \mathrm{M}\right)$ in the presence and absence of $\mathrm{AT}_{1}$ receptor blockade $\left(10^{-4} \mathrm{M}\right.$ losartan; MSD, Haarlem, The Netherlands). Furthermore, adipocytes were incubated with $N^{6}$-(2-phenylisopropyl)adenosine (PIA: $100 \mathrm{nM}$ ) (Sigma-Aldrich) as a control point for maximal inhibition of lipolysis in the incubation system.

Statistical analysis. Data are mean \pm standard error of the mean (s.e.m.). Lipolytic rates are presented as relative changes from baseline because of interindividual variation in baseline glycerol concentrations. Effects of Ang II were compared by two-way repeated measures analysis of variance (ANOVA), using dose as within-subject factor and group or treatment as between-subject factor. One-way repeated measures ANOVA was performed to identify dose effects. $P<0.05$ was considered to be statistically significant, using SPSS 10.1 (Chicago, IL, USA).

\section{Results and discussion}

Basal lipolytic rates were not significantly different between normal weight and obese subjects $(4.8 \pm 1.1$ vs $11.4 \pm 5.1 \mu \mathrm{mol} \times 10^{7}$ cells $^{-1} \times 2 \mathrm{~h}$ incubation $^{-1}$, respectively, $P=0.24)$. Ang II significantly inhibited adipocyte lipolysis in normal weight $(P=0.04)$ and obese subjects $(P<0.001)$ (Figure 1a), with no differences between groups $(P=0.40)$. In the second experiment, basal lipolytic rate was $5.0 \pm 1.0 \mu \mathrm{mol} / 10^{7}$ cells $/ 2 \mathrm{~h}$ incubation. Ang II dose dependently inhibited lipolysis by $\sim 20-25 \%(P=0.001)$, and this effect was completely abolished by $\mathrm{AT}_{1}$ receptor blockade $(P=0.35)$ (Figure $1 \mathrm{~b})$.

These findings demonstrate that Ang II inhibits lipolysis through the $\mathrm{AT}_{1}$ receptor in abdominal subcutaneous adipocytes in normal weight and obese subjects. PIA, used as a control point for maximal inhibition of lipolysis in the incubation system, ${ }^{16}$ reduced the lipolytic rate by $\sim 40 \%$
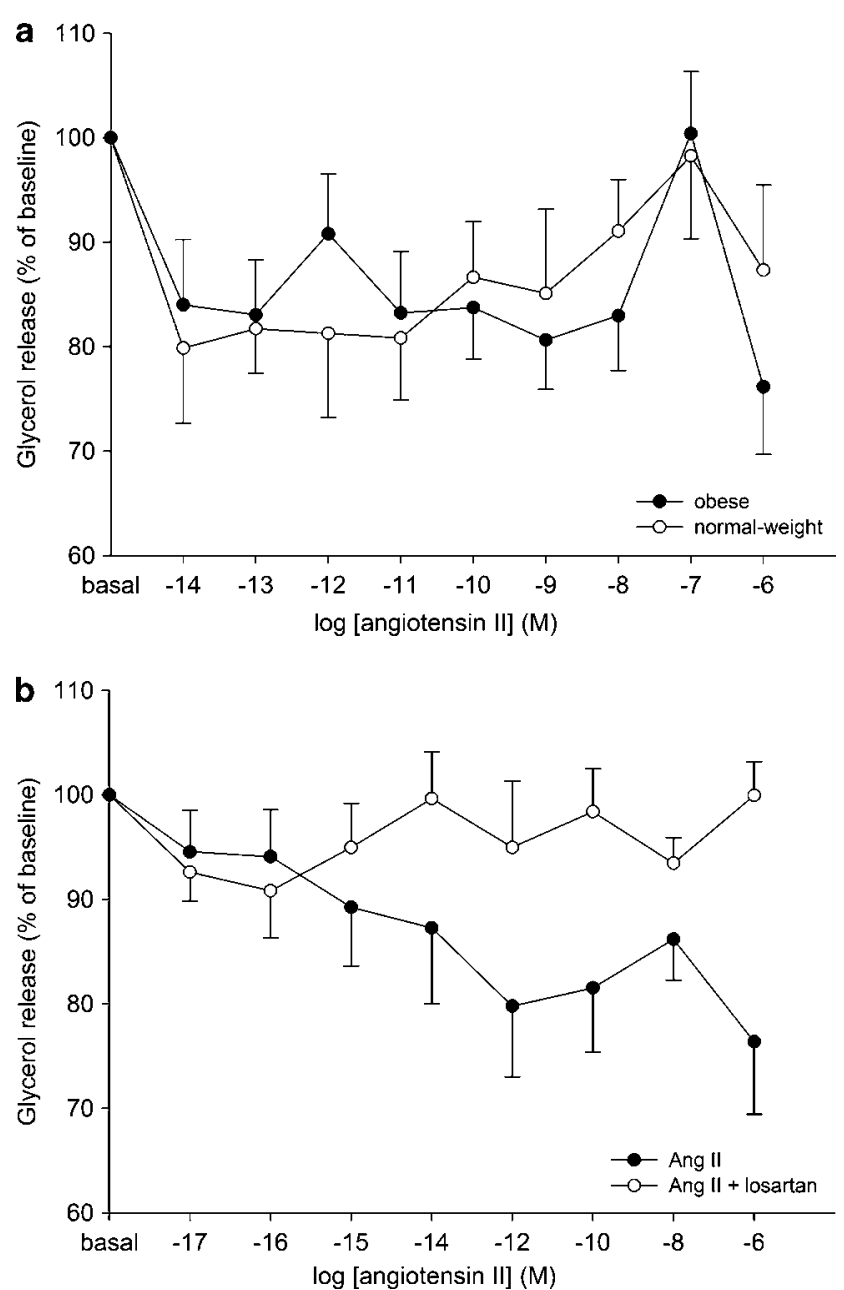

Figure 1 (a) Effects of Ang II stimulation on glycerol release from abdominal subcutaneous adipocytes from nine normal weight and seven obese subjects. Ang II reduced glycerol release both in normal weight $(P=0.04$ by one-way repeated-measures ANOVA) and obese subjects $(P<0.001$ by one-way repeated-measures ANOVA), with no differences between groups $(P=0.40$ by two-way repeated-measures ANOVA). Values are means \pm s.e.m. (b) Effects of Ang II stimulation on glycerol release from abdominal subcutaneous adipocytes from seven obese subjects in the presence and absence of $\mathrm{AT}_{1}$ receptor blockade $\left(10^{-4} \mathrm{M}\right)$. Glycerol release was dose dependently reduced during stimulation with Ang II $(P=0.001$ by one-way repeated-measures ANOVA). Ang II had no significant effects on lipolysis in the presence of $A T_{1}$ receptor blockade ( $P=0.35$ by one-way repeated-measures ANOVA). Values are means \pm s.e.m.

$(P<0.01)$ (data not shown). Therefore, the observed $\sim 20-25 \%$ reduction of glycerol release after Ang II stimulation reflects a substantial inhibition of lipolysis. The normal circulating Ang II concentration is $10 \mathrm{pm} .{ }^{17}$ It has previously been shown that Ang II concentrations are $\sim 2-3$-fold higher in the incubation medium of (pre)adipocytes than in the circulation. ${ }^{4,7}$ Because stimulation of adipocytes with physiological concentrations of Ang II evoked near-maximal inhibition of lipolysis in the present experiments, Ang II may not play an important role in the regulation of adipocyte lipolysis. Instead, Ang II may exert a tonic suppression of adipocyte lipolysis. 
The present findings are in line with previous observations suggesting that Ang II inhibits adipose tissue lipolysis in humans. ${ }^{13}$ In contrast, no effect of Ang II on insulin-induced suppression of lipolysis was observed in obese women. ${ }^{18}$ In addition to methodological differences compared with the present study, insulin may have masked a less pronounced antilipolytic effect of Ang II. In a rat model for increased RAS activity in cachectic patients with advanced heart failure, lipolysis was increased in some but not all fat depots. ${ }^{19}$ Because expression of (anti)lipolytic receptors differs between species, ${ }^{19}$ and the high Ang II concentrations activated the sympathetic nervous system, it is difficult to extrapolate these findings to Ang II effects on adipocyte lipolysis in humans.

It has been shown that Ang II exerts lipogenic effects in human adipocytes ${ }^{12}$ and inhibits adipocyte differentiation. ${ }^{11}$ Although Ang II effects in adipose tissue may not be involved in the expansion of fat mass, they may contribute to a reduced buffering capacity for lipid storage in adipose tissue in the long term, leading to an excessive influx of lipids to other tissues. ${ }^{10}$

In conclusion, Ang II inhibits lipolysis via the $\mathrm{AT}_{1}$ receptor in abdominal subcutaneous adipocytes from normal weight and obese subjects. The present findings support the concept that the RAS in adipose tissue participates directly in fat metabolism and may contribute to the metabolic disturbances seen in obesity. This study was not designed to examine underlying signalling pathways, but focused on lipolysis as cellular end point. Identification of the underlying mechanisms for the antilipolytic effect of Ang II in human adipocytes may provide better insight into possible interactions between (anti)lipolytic pathways.

\section{Acknowledgements}

We thank Kerstin Wåhlén, Eva Sjölin and Freek Bouwman for excellent technical assistance. Losartan was provided by Merck Sharp and Dohme (Haarlem, The Netherlands).

\section{References}

1 Lafontan M. Fat cells: afferent and efferent messages define new approaches to treat obesity. Annu Rev Pharmacol Toxicol 2005; 45: 119-146.
2 Arner P. Insulin resistance in type 2 diabetes - role of the adipokines. Curr Mol Med 2005; 5: 333-339.

3 Kershaw EE, Flier JS. Adipose tissue as an endocrine organ. J Clin Endocrinol Metab 2004; 89: 2548-2556.

4 Schling P, Schafer T. Human adipose tissue cells keep tight control on the angiotensin II levels in their vicinity. J Biol Chem 2002; 277: 48066-48075.

5 Karlsson C, Lindell K, Ottosson M, Sjostrom L, Carlsson B, Carlsson LM. Human adipose tissue expresses angiotensinogen and enzymes required for its conversion to angiotensin II. J Clin Endocrinol Metab 1998; 83: 3925-3929.

6 Crandall DL, Herzlinger HE, Saunders BD, Armellino DC, Kral JG. Distribution of angiotensin II receptors in rat and human adipocytes. J Lipid Res 1994; 35: 1378-1385.

7 Schling P, Mallow H, Trindl A, Loffler G. Evidence for a local renin angiotensin system in primary cultured human preadipocytes. Int J Obes Relat Metab Disord 1999; 23: 336-341.

8 Goossens GH, Blaak EE, van Baak MA. Possible involvement of the adipose tissue renin-angiotensin system in the pathophysiology of obesity and obesity-related disorders. Obes Rev 2003; 4: $43-55$.

9 Strazzullo P, Galletti F. Impact of the renin-angiotensin system on lipid and carbohydrate metabolism. Curr Opin Nephrol Hypertens 2004; 13: 325-332.

10 Sharma AM, Janke J, Gorzelniak K, Engeli S, Luft FC. Angiotensin blockade prevents type 2 diabetes by formation of fat cells. Hypertension 2002; 40: 609-611.

11 Janke J, Engeli S, Gorzelniak K, Luft FC, Sharma AM. Mature adipocytes inhibit in vitro differentiation of human preadipocytes via angiotensin type 1 receptors. Diabetes 2002; 51: 1699-1707.

12 Jones BH, Standridge MK, Moustaid N. Angiotensin II increases lipogenesis in 3T3-L1 and human adipose cells. Endocrinology 1997; 138: 1512-1519.

13 Goossens GH, Blaak EE, Saris WH, van Baak MA. Angiotensin IIinduced effects on adipose and skeletal muscle tissue blood flow and lipolysis in normal-weight and obese subjects. J Clin Endocrinol Metab 2004; 89: 2690-2696.

14 Rodbell M. Metabolism of isolated fat cells: effects of hormones on glucose metabolism and lipolysis. J Biol Chem 1964; 239: 375-380.

15 Hellmer J, Arner P, Lundin A. Automatic luminometric kinetic assay of glycerol for lipolysis studies. Anal Biochem 1989; 177: 132-137.

16 Johnson JA, Fried SK, Pi-Sunyer FX, Albu JB. Impaired insulin action in subcutaneous adipocytes from women with visceral obesity. Am J Physiol Endocrinol Metab 2001; 280: E40-E49.

17 Campbell DJ, Kladis A. Simultaneous radioimmunoassay of six angiotensin peptides in arterial and venous plasma of man. J Hypertens 1990; 8: 165-172.

18 Perry CG, Palmer T, Cleland SJ, Morton IJ, Salt IP, Petrie JR et al. Decreased insulin sensitivity during dietary sodium restriction is not mediated by effects of angiotensin II on insulin action. Clin Sci (London) 2003; 105: 187-194.

19 Cabassi A, Coghi P, Govoni P, Barouhiel E, Speroni E, Cavazzini S et al. Sympathetic modulation by carvedilol and losartan reduces angiotensin II-mediated lipolysis in subcutaneous and visceral fat. J Clin Endocrinol Metab 2005; 90: 2888-2897. 